\title{
Utilization of Oil Palm Midrib Waste for Particleboard with an Adhesive Mixture of Phenol Formaldehyde and Acacia Tannin
}

\author{
Dr. Ir.Darni Subari,MS
}

\begin{abstract}
Oil palm midrib is solid waste from oil palm plantation with huge potential of 20 ton/ha/year (Sayed Umar, 2009). This lignocellulosic material can be optimally utilized for particleboard. Acacia bark is also organic waste from the manufacture of acacia chip, containing tannin whose properties similar to adhesive, so that it is called bio-adhesive. In this research, tannin functions as the extender for Phenol Formaldehyde adhesive in the manufacture of particleboard from oil palm midrib. The objective of the research was to find out the characteristics of oil palm midrib for particleboard with a mixture variation of Phenol Formaldehyde $(P F)$ and tannin. The research employed the factorial experiment with complete random design, where factor $A$ consisted of two levels, i.e. PF adhesive compositions of $8 \%$ and $10 \%$, and factor B consisted of 4 levels, i.e. tannin additions of $0 \%, 2.5 \%, 5 \%$ and $10 \%$ of $P F$ adhesive weight. The result indicated that the physical properties of oil palm midrib particleboard (KA and density), the mechanical properties (MOR, IB and screw holding strength), and some parts of MOE from the PF use of 10\% could meet SNI (Indonesian National Standard) 03-2105-1996.
\end{abstract}

Keywords: particleboard, oil palm midrib, Phenol Formaldehyde, acacia tannin

\section{Introduction}

Oil palm midrib is solid waste from oil palm plantation, which is quite a lot in number but still limited in its utilization until now. The midrib has potential to be utilized as the raw material for particleboard because it contains lignocelluloses.

The research about the manufacturing of particleboard from oil palm midrib is relatively small although it has big potential considering that the midribs are periodically degraded because the oil palm trees always keep growing. One hectare of oil palm plantation will produce midribs at about 20,000 kg/year from 22 -26 midribs per a tree, each of which weighs $7 \mathrm{~kg}$, in a year. There are approximately 130 oil palm trees in one hectare (Sayed Umar, 2009). With the assumption that there were about 9 million hectares of oil palm in 2010, in one year there would be $180,000,000$ tons of oil palm midribs spread almost all over the Indonesian archipelago.

The particleboard as the panel product can utilize the particles of oil palm midrib and bind them with a resin as the binder. The particleboard, which is similar to the rough fiberboard, is one of the solutions to fulfill the demand of board especially for the furniture and the interior as well as the household appliances.

The environmentally friendly binding material is a requirement that recently becomes an issue to the society, either about its raw or supporting material resources. Tannin is the extraction product of bark or wood that should be developed because it has such a characteristic. The results of some researches showed the successfulness of tannin utilization as the natural adhesive, and some of its shortcomings that need to be improved to optimize the tannin potential as the adhesive (Adi Santoso and Rachman O, 2005)

The potential of bark waste from industrial crop forest / Hutan Tanaman Industri (HTI) especially from acacia species (Acacia mangium) in the future would be huge with the more support to HTI of acacia. With the calculation that the barks are about $10 \%$ of the log, the bark waste produced will be about more than 3 million tons per year (Prasetya, 1995). One of the benefits of the bark is that it contains tannin. The researches about the utilization of tannin product from the extraction process as the raw material for the bark adhesive have been widely conducted (Pizzi, 1982; Subyakto et al. 1996; Prasetya et al. 1998, Prasetya et al. 2000). The process of tannin extraction requires chemical substance and some expensive equipment. However, the extraction of tannin with hot water, which is simple and inexpensive, can be carried out to produce tannin.

In addition to its direct utilization as the adhesive, tannin is usually mixed with syntactical adhesive, such as Phenol Formaldehyde adhesive, to improve its usage.

Subyakto and Prasetyo, 2003., the wood powder of acacia bark is used as the adhesive for particleboard without extraction, which is mixed with particle powder of sengon (Paraserianthes falcataria) with the size of 15 mesh in the variations of $50: 50 ; 60: 40 ; 80: 20$, and added with water and phenol formaldehyde, on the pressure of $10 \mathrm{~kg} / \mathrm{cm}^{2}$ and the heat press of $180^{\circ} \mathrm{C}$. The best result of the research was the mixture at the composition of $60: 40$, because it met the standard of JIS A 5908, i.e. the density of $0.66 \mathrm{~g} / \mathrm{cm}^{3}$, the water content of $10.87 \%$ and the screw holding strength of $3.61 \mathrm{kgf} / \mathrm{cm}^{2}$, MOR of $140.5961 \mathrm{kgf} / \mathrm{cm}^{2}$, MOE of $17.2461 \mathrm{kgf} / \mathrm{cm}^{2}$. 
Subyakto et al. 2005, utilized acacia wood from Sumatera aged 10 years to produce 10-mesh particles added with rough bark particles in the ratio of $1: 2$ with phenol formaldehyde adhesive. The pressing temperature was $150^{\circ} \mathrm{C}$ with the pressure of $20 \mathrm{~kg} / \mathrm{cm}^{2}$, and the pressing time was 15 minutes. The content variations of Phenol Formaldehyde adhesive were 4\%, 6\%, and 8\%; added with water $10 \%$ of the particle dry weight in order to make the board with the density target of $0.7-0.9 \mathrm{~g} / \mathrm{cm}^{3}$. It resulted in the board with higher density from the target with the water content ranging from $12.08-13.36 \%$. It can be concluded that the particleboard from acacia bark (A. mangium Wild) with the PF mixtures of $6 \%$ and $8 \%$, which produced the density of $0.9 \mathrm{~g} / \mathrm{cm}^{3}$, could meet the standard JIS A5908 for BI and MOR, while the value of MOE and the thickness swelling did not meet it.

\section{Materials and equipment}

\section{Research Methods and Materials}

The materials used in the research were midrib particles of oil palm passing a 15-mesh screen, tannin from acacia bark extraction, and Phenol Formaldehyde adhesive.

The equipment was a measuring cylinder, erlenmeyer flask, glass cup, electronic scales, spatulas, moisture meter, $\mathrm{pH}$ paper, Visco meters, hot forged instrument, capillary, board printing equipment, oven and stationery.

\section{Methods}

\subsection{Preparations of Materials}

a. Determination of Rendement and Tannin Characteristics

The determination of tannin content and its characteristics was conducted in order to determine the content of tannin from the acacia bark. Tannin had the characteristics like the following:

Table 1. Quality and Quantity of Tannin Extracted by Using Hot Water

\begin{tabular}{|c|c|c|c|c|}
\hline Treatment & Rendement (\%) & Water Content & Solid Content & Ash Content \\
\hline Powder (3 hours) & 4.75 & 11.36 & 3.75 & 2.63 \\
\hline Powder (5 hours) & 5.64 & 10.78 & 3.45 & 3.66 \\
\hline Minced (3 hours) & 3.30 & 13.92 & 2.66 & 3.51 \\
\hline Minced (5 hours) & 3.90 & 14.22 & 3.15 & 2.27 \\
\hline
\end{tabular}

Tannin extracted by using hot water would be mixed into a component of extender in phenol formaldehyde adhesive.

b. Preparation for Oil Palm Midrib Particles

The oil palm midribs were dried and then chopped into some small pieces and put in the hammermill for the process of becoming particles. The particles were dried in the oven until their water content was about 4$6 \%$, and then sifted to eliminate the powder-shape materials. The particles taken were the ones did not pass the 15 -mesh screen.

c. Phenol Formaldehyde Adhesive

Phenol Formaldehyde (PF) used was the adhesive that was ready to use with the specifications like the following: Phenol Formaldehyde (PA-302), in the form of dark red liquid, $\mathrm{pH}$ at about $10.0-13.6$ with the viscosity of $1.5-3.0$ poise, specific gravity of $1.180-1.200$ and the solid content of $41.0-43.0$.

\subsection{Particleboard Manufacturing}

Particles were weighed in accordance with the requirements for becoming a board with the target of flatness of $0.70 \mathrm{~g} / \mathrm{cm}^{3}$ sized $30 \mathrm{~cm} \times 30 \mathrm{~cm} \times 1 \mathrm{~cm}$. The PF adhesive as much as $10 \%$ and $8 \%$ were used as the binders, then each would be treated by adding powdered tannins as much as $0 \%, 2.5 \%, 5 \%$, and $10 \%$ of the PF weight. The adhesive mixture made from tannin and PF powder was stirred by using a mixer until evenly mixed. The prepared adhesive was mixed into the palm midrib particles and pressed with the given temperature and pressure of $25140 \mathrm{~kg} / \mathrm{cm}$ for 10 minutes.

Particleboards that had been manufactured were aerated for 1 week. Further testing of physicalmechanical properties of the particleboard with the standard of SNI 03-2105-1996 was conducted, including water content, density, thickness swelling, water absorption, Internl Bond, MOE, MOR and screw holding strength.

\section{Data Analysis}

This study employed a factorial experiment with a completely randomized design patterns (CRD), with 3 time replications. The treatment factors in this study were the composition of phenol formaldehyde (PF) and 
tannin content in the particleboard. The treatments for the composition of the phenol formaldehyde (PF) in the particleboard. consisted of two levels, namely $10 \%$ and $8 \%$ of the particle weight for a board, while the contents of tannin in the particle-board consisted of 4 levels, namely $0 \%, 2.5 \%, 5 \%$ and $10 \%$ of the phenol formaldehyde weight.

\section{Properties of PF Adhesive and Tannin}

\section{Empirical Result}

The PF adhesive used was ready-made (factory-made), in the form of brownish red liquid, with the typical odor of phenol. The characteristics of the adhesive mixed with tannin can be seen in Table 2 .

Table 2. Characteristics of Adhesive

\begin{tabular}{|l|c|c|c|c|}
\hline \multirow{2}{*}{ Parameter } & \multirow{2}{*}{ Tannin (extender) } & \multicolumn{3}{|c|}{ Value } \\
\cline { 2 - 5 } & & $\mathbf{1 0 \%}$ & $\mathbf{8 \%}$ & SNI \\
\hline Viscosity & 0 & 5.0 & $1.3-3.0$ & 6.2 \\
& 2.5 & 7.0 & 7.0 & $1.3-3.0$ \\
& 5 & 9.0 & 11.0 & \\
$\mathrm{nH}$ & 10 & 12.0 & $11.0-13.0$ & \\
& 0 & $11.0-13.0$ & $11.0-13.0$ & $10.0-13.0$ \\
& 2.5 & $;$ & $11.0-13.0$ & \\
\end{tabular}

The PF adhesive after mixed with tannin showed the increase in viscosity adhesive. According to Cowd 1991 in Susanti 2005, in the process of polymerization polymer properties were produced by relative molecular masses and the composition contained in the polymer or the degree of crystalline materials. Polymerization caused an increase in viscosity of the material, so that the viscosity value increased and the gelatinization time decreased. The degree of acidity $(\mathrm{pH})$ would also tend to increase but the value was still within the threshold of ISO 1996.

\section{Physical Properties of Particleboard}

The test result of the physical properties of the particleboard is presented in Table 2. Based on the mean values, there were no thickness swelling and water absorption behaviours found in the particleboard. The particleboard meeting the good standard of SNI 03-2105-1996 was the particleboard type 100. The statistical test was used to indicate all factors influencing such a condition. The mean values from the result of mechanical properties testing is shown in Table 3.

Table 3: Mean values of physical properties of oil palm midrib particleboard with PF adhesive and Tannin

\begin{tabular}{|c|c|c|c|c|c|}
\hline \multirow[t]{2}{*}{ Total PF (\%) } & \multirow{2}{*}{$\begin{array}{c}\text { Composition of } \\
\text { Tannin }(\%)\end{array}$} & \multicolumn{4}{|c|}{ Physical Properties } \\
\hline & & KA $(\%)$ & $\begin{array}{c}\partial \\
(\mathrm{gr} / \mathrm{cm} 3)\end{array}$ & $\begin{array}{c}\text { Thickness } \\
\text { Swelling (\%) }\end{array}$ & $\begin{array}{c}\text { Water Absorption } \\
(\%)\end{array}$ \\
\hline \multirow{4}{*}{8} & 0 & 7.65 & 0.72 & 65.27 & 91.54 \\
\hline & 2.5 & 6.67 & 0.73 & 51.14 & 94.52 \\
\hline & 5 & 5.21 & 0.76 & 49.59 & 108.20 \\
\hline & 10 & 8.01 & 0.75 & 56.31 & 105.75 \\
\hline \multirow{4}{*}{10} & 0 & 7.61 & 0.77 & 37.75 & 75.22 \\
\hline & 2.5 & 6.28 & 0.79 & 57.29 & 94.44 \\
\hline & 5 & 5.90 & 0.78 & 56.20 & 97.06 \\
\hline & 10 & 9.26 & 0.72 & 62.50 & 98.41 \\
\hline \multicolumn{2}{|c|}{ SNI-03-2105-1996 } & $<14$ & $0.40-0.90$ & $<12$ & $<20$ \\
\hline
\end{tabular}

Note:

KA $=$ Water content of particleboard

$\partial \quad=$ Density of particleboard

The particleboard produced mostly met the targeted density standard, i.e. $0.70 \mathrm{~g} / \mathrm{cm}^{3}$. Likewise, the water content of the particleboard met the standard of SNI-03-2105-1006, i.e. $<14 \%$. The thickness swelling testing indicated that none of the tested particleboards met the standard. Although the water absorption testing was not specified in SNI 1996, it was stated in SNI-2006 that the maximal absorption for the ordinary particleboard with the thickness of $>12.77 \mathrm{~mm}$ must not be more than $20 \%$. In order to clearly describe the role of the adhesive, the anova table is presented in Table 4. 
Table 4. Anova for test results of water content and density of particleboard with PF adhesive and tannin

\begin{tabular}{|l|c|c|c|c|c|c|}
\hline \multirow{2}{*}{$\begin{array}{c}\text { Variation } \\
\text { Sources }\end{array}$} & Density & Water Content & $\begin{array}{c}\text { Water } \\
\text { Absorption }\end{array}$ & $\begin{array}{c}\text { Thickness } \\
\text { Swelling }\end{array}$ & \multicolumn{2}{|c|}{ Ftab } \\
\cline { 2 - 7 } & Fhit & Fhit & Fhit & Fhit & $5 \%$ & 4.49 \\
\hline PF Composition & $0.28 \mathrm{tn}$ & $0.17 \mathrm{tn}$ & $10.34 * *$ & $1.62 \mathrm{tn}$ & 3.24 & 5.29 \\
\hline $\begin{array}{l}\text { Tannin } \\
\text { Composition }\end{array}$ & $5.57^{* *}$ & $2.24 \mathrm{tn}$ & $3.54 *$ & $1.10 \mathrm{tn}$ & 3.53 \\
\hline Interaction & $1.141 \mathrm{tn}$ & $0.17 \mathrm{tn}$ & $0.55 \mathrm{tn}$ & $3.68^{* *}$ & 3.24 & 5.29 \\
\hline
\end{tabular}

$* *$ highly significant at alpha $=0.01 ; *$ significant at alpha $=0.05 ;$ tn $\sim$ not significant at alpha $=0.05$

The table shows that there was no significant effect of the treatment on the water content of particleboard, either by the factor of PF adhesive or tannin and their interaction. However, the test result showed that the board met the specified standard, namely $<14 \%$.

On the test of board density, the standard could also be met, namely $0.70 \mathrm{~g} / \mathrm{cm}^{3}$. On the test of particleboard density, however, it was only tannin having the effect on the density of the tested boards; the value of $\mathrm{R} 2=0.56$, indicating that $56 \%$ of the treatment gave the effect on the board density and the most significant factor was tannin.

On the test of water absorption, the result showed that all the treatment factors given, namely PF and tannin, gave a highly significant effect, with the value of $\mathrm{R} 2=0.59$. The statistical test on the thickness swelling testing was with the value of $\mathrm{R} 2=0.50$. The following Histogram is presented to make the results of the tests clearer compared to the standard of SNI-03-2105-1996.
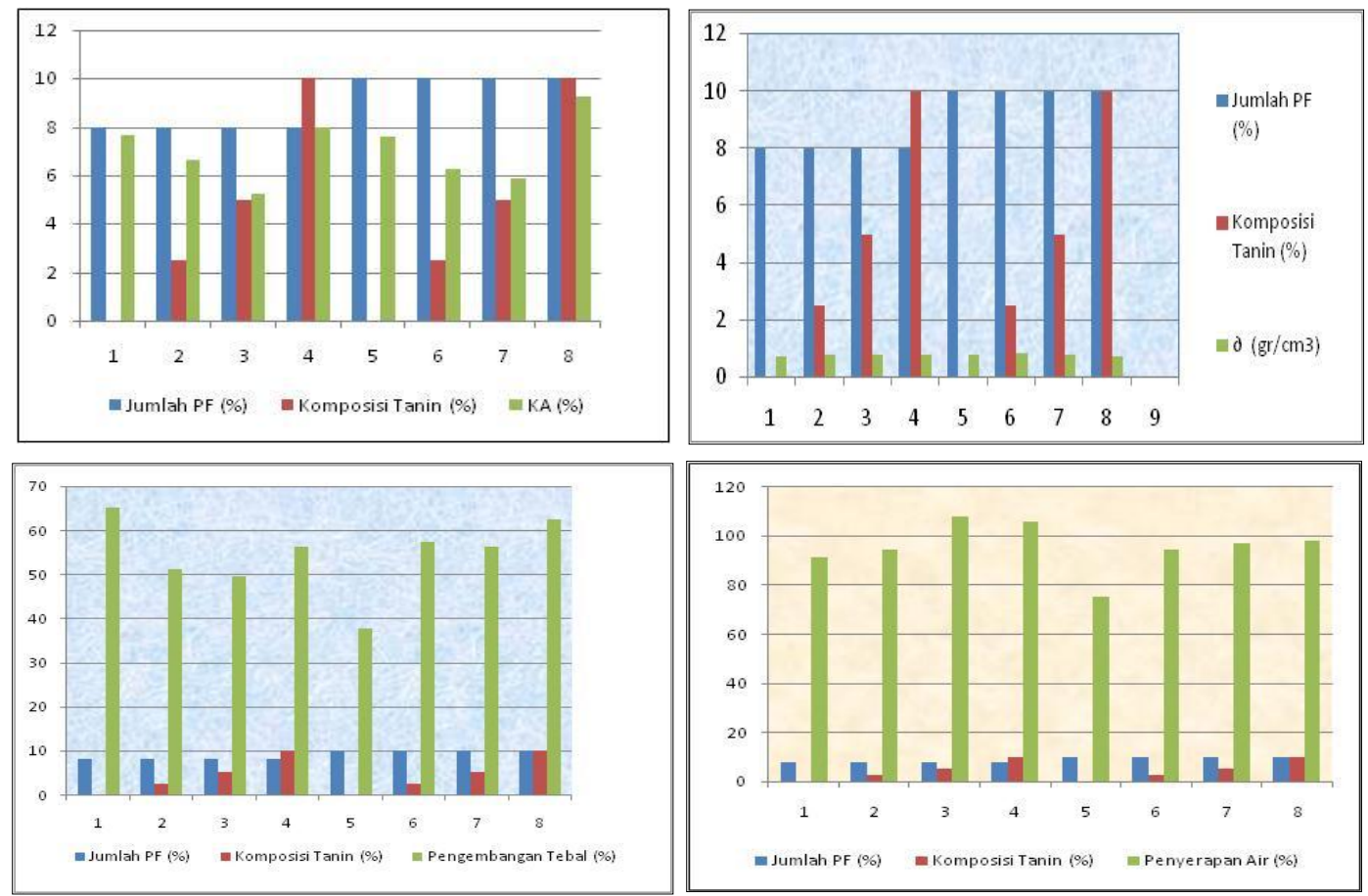

Figure 1 : Histogram of density, water content, thickness swelling and water absorption of oil palm midrib particleboard with PF adhesive + Tannin

When the oil palm midrib particleboard with PF adhesive and tannin was compared to the acacia tree bark particleboard with PF adhesive (Subyakto et al. 2005), the physical properties of this particleboard were much better especially on the water content test which all was $<14 \%$, while KA was $>12 \%$. Tannin is, therefore, better used in the extract form before it is mixed with PF adhesive.

Tsoumis, 1991, stated that the density of the particleboard is affected by the wood density and will increase $5-10 \%$ of the wood density. The addition of the adhesive will affect the density and produce the heavier board. It could be identified that there was an increase in the density of the specified target.

Hadi, YS, 1998, suggested that the particleboard properties are affected by the raw material, the adhesive, and the formulation used as well as the process of the production. 


\section{Mechanical Properties of Particleboard}

The result of the mechanical properties testing of the particleboard is presented in Table 5. The difference of the adhesive composition made the mechanical properties less than the standard, i.e. MOE properties at PF composition of $8 \%$ without tannin and with tannin of 5-10\%, and on the MOR testing with the composition of $8 \% \mathrm{PF}+10 \%$ tannin. The rest of the tests showed that all properties met the standard.

The tabulation data from MOE test obtained the value of $R^{2}=0.50$ and MOR with the value of $R^{2}=$ 0.64 , indicating that the given treatment only affected MOE up to 50\% and MOR 64\%, and all the significantly influencing factor was PF adhesive. Furthermore, at the internal bond factor, the provision of PF adhesive and tannin was highly significantly influencing, so was the screw holding strength, with $\mathrm{R} 2 \mathrm{IB}=0.80$ and the screw holding strength R2 $=0.59$.

Table 5. Mean values of mechanical properties of oil palm midrib particleboard with PF adhesive and tannin

\begin{tabular}{|c|c|c|c|c|c|}
\hline $\begin{array}{c}\text { Composition of } \\
\text { PF (\%) }\end{array}$ & $\begin{array}{c}\text { Composition of } \\
\text { Tannin (\%) }\end{array}$ & IB (kg/cm2) & $\begin{array}{c}\text { Screw Holding } \\
\text { Strength (kg) }\end{array}$ & $\begin{array}{c}\text { MOR } \\
(\mathbf{k g f} / \mathbf{c m} 2)\end{array}$ & $\begin{array}{c}\text { MOE } \\
(\mathbf{k g f} / \mathbf{c m} 2)\end{array}$ \\
\hline \multirow{3}{*}{8} & 0 & 1.9 & 44.5 & 88.3 & 13.677 \\
\cline { 2 - 6 } & 2.5 & 1.6 & 38.1 & 93.4 & 15.297 \\
\cline { 2 - 6 } & 5 & 1.5 & 34.8 & 91.5 & 11.937 \\
\cline { 2 - 6 } & 10 & 1.5 & 32.0 & 50.6 & 7.681 \\
\hline \multirow{3}{*}{10} & 0 & 2.1 & 55.3 & 118.1 & 17.277 \\
\cline { 2 - 6 } & 2.5 & 1.8 & 45.3 & 11.2 & 21.585 \\
\cline { 2 - 6 } & 5 & 1.5 & 38.6 & 119.4 & 15.927 \\
\cline { 2 - 6 } & 10 & $\mathbf{1 . 5}$ & $\mathbf{3 0}$ & $\mathbf{8 0}$ & 19.083 \\
\hline SNI-03-2105-1996 & & & & $\mathbf{1 5 . 0 0 0}$ \\
\hline
\end{tabular}

Note:

IB $=$ Internal Bond

MOR = Modulus of Repture

MOE = Modulus of Elasticity

Table 6. Anova for MOE and MOR of oil palm midrib particleboard with PF adhesive and tannin

\begin{tabular}{|l|c|c|c|c|c|c|}
\hline \multicolumn{2}{|l|}{ Variation Source } & MOE & MOR & IB & Bolt & \multicolumn{2}{|c|}{ Ftab } \\
\cline { 2 - 7 } & Fhit & Fhit & Fhit & Fhit & $\mathbf{5 \%}$ & $\mathbf{1 \%}$ \\
\hline $\begin{array}{l}\text { Composition of } \\
\text { PF }\end{array}$ & 9.22 & 15.33 & $10.27^{* *}$ & $4.64^{* *}$ & 4.49 & 8.53 \\
\hline $\begin{array}{l}\text { Composition of } \\
\text { tannin }\end{array}$ & $1.03 \mathrm{tn}$ & $2.80 \mathrm{tn}$ & $25.54^{* *}$ & $5.63^{* *}$ & 3.24 & 5.29 \\
\hline Interaction & $1.33 \mathrm{tn}$ & $1.60 \mathrm{tn}$ & 1.81 & 0.50 & 3.24 & 5.29 \\
\hline
\end{tabular}

$* *$ Highly significant at alpha $=0.01 ; *$ significant at alpha $=0.05 ;$ tn $\sim$ not significant at alpha $=0.05$
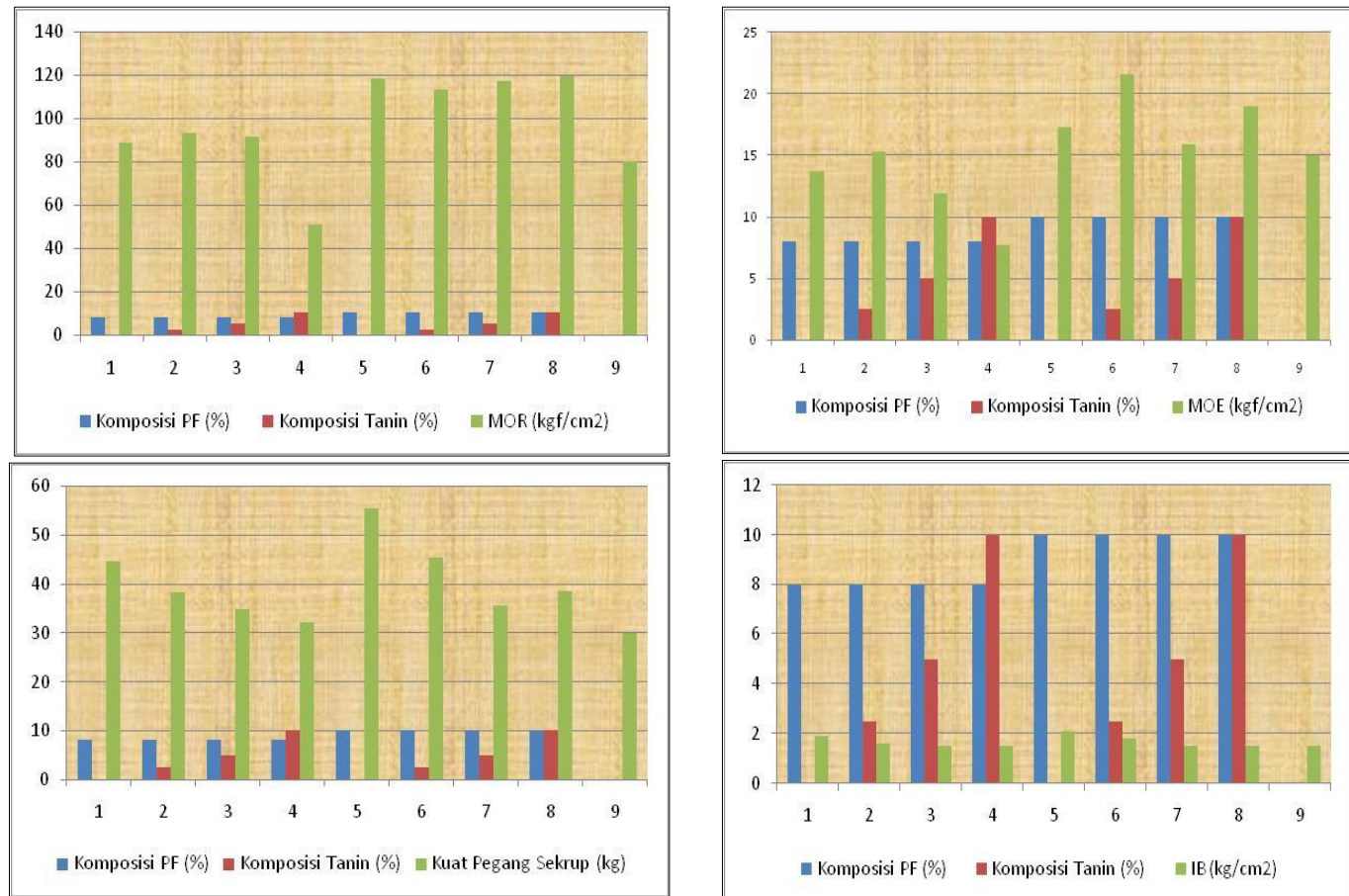

Figure 2. Histogram of MOR, MOE, IB and screw holding strength compared to standard of SNI 1996 on oil palm midrib particleboard with PF adhesive and tannin 
Compared to the research of Subyakto et al. 2005, the oil palm midrib particleboard with the composition of PF adhesive with or without the addition of tannin, indicated much better result. It could be concluded that beside the type and size of the particles used, the addition of extracted tannin as the PF adhesive extender could increase the quality of the praticleboard, since it met the specified standard. The exception was on MOE test at the PF composition of $8 \%$ with the tannin composition of 5\% and $10 \%$. The MOE strength decreased. Although the tannin role was not statistically significant, the PF role was highly significant. Based on the statistical test, the factor playing the role in this property was phenol formaldehida adhesive, not tannin.

Soebiyakto et al. 2005, conducting the research on the utilization of acacia wood from Sumatera with the treatment of Phenol Formaldehyde 6\% and 8\%, stated that it could meet the standard of JIS A 5908.

\section{Conclusion}

It can be concluded that the particleboard made of oil palm midrib manufactured by using phenol formaldehyde adhesive or by adding tannin extender showed the following properties:

1. The physical properties, especially the density and the water content met the standard of SNI-1996, i.e. $0.70 \mathrm{gr} / \mathrm{cm}^{3}$ and $<14 \%$ for the density and the water content, respectively.

2. Although it could meet the specified standard, the given treatment factor did not show the significant effect except to the tannin factor on the density test of particleboard.

3. The values obtained from the water absoption and the thickness swelling tests could not meet the standard, but the factor of the utilization of PF adhesive and tannin gave a highly significant effect.

4. The mechanical properties test, especially MOE and MOR for the most part met the standard, and the effect of the PF adhesive was highly significant in these properties.

\section{References}

[1] Adi Sujasman, 2009. Supply of Oil Palm Wood Particle Board with Unsaturated Polyester Resin (Yukalac 157 BQTN-Ex), Postgraduate School, University of Sumatera Utara, Medan

[2] Adi Santoso and Yusuf Sudohadi, 2005. Low Formaldehyde Emission Particleboard Using Tannin Adhesive. Journal of Forest Product Technology. Forestry Faculty of Institut Pertanian Bogor. Vol 18. No.1. 2005

[3] Adi Santoso and Rachman O, 2005. Use of Condensed Tannin of Acacia Bark for Wood Adhesive. Journal of Forestry Research Wana Mukti.Vol.2. No.2 2005

[4] Cecilia Maria Erna Susanti, 2000. Tannin Autocondensate and Its Use as Lamina Wood Adhesive. Postgraduate Program of Institut Pertanian Bogor, Thesis. Unpublished.

[5] Fengel, D. dan G. Wegener, 1995. Wood: Chemistry, Ultrastructure, Reactions. Translated by Sastrohamidjoyo, edited by Prawirohatmodjo. Gajah Mada University Press, Yogyakarta.

[6] Hathway, D. E. 1962. The Condensed Tannins. In Wood Extractives (Hillis W. E). Academic Press. New York.

[7] Hadi, YS, 1988. Effects of Heat Immersion of Wood Particleboard on Dimension of Industrial Waste Particleboard. Bulletin of Forestry Product Technology Department, 1:6-23

[8] Haygreen, J. G a nd J. L Bowyer. 1989. Forestry Products and Wood Science. Gadjah Mada University Press. Yogyakarta.

[9] Hunt, G. M dan G. A. Garrat. 1986. Wood Preservation. Akademica Pressindo. Jakarta.

[10] Hemingway R.M., P.E. Laks, G. W. Me Graw, and RE. Kreibich, in Wood Adhesive in 1885 : Status and Needs, Forest Products Research Society, Madison, Wis.,1986.

[11] Markham, K. R. 1988. Ways to Identify Flavonoid. Translation. Institut Teknologi Bandung. Bandung.

[12] Pizzi, A., 1983. Chapter 4 in Wood Adhesives : Chemistry and Technology. Vol I (A. Pizzi ed), Maecell Dekker, New York.

[13] Pizzi, A.. 1994.Chaper 5 in Advanced Wood Adhesive Technology : Tannin-Base Wood Adhesives, Marcel Dekker, Inc, New York- Basel- Hongkong.

[14] Pizzi, A., N. Meikleham, B. Dombo and W. Roll. 1995. Autocondensation-based, Zero- Emission, Tannin adhesives for particleboard. Holz als Roh-und Werkstoff. 53(1):201-204.

[15] Ruhendi, S., D. N. Koroh, F.A. Samani, H. Yanti, Nurhaida, S. Saad, dan T. Sucipto, 2007. Analysis of Wood Adhesion. Forestry Faculty of IPB, Bogor.

[16] Sayed Umar, 2009. Speech in Inauguration of Permanent Professorship in Cattle Reproduction Science of Agricultural Faculty, University of Sumatera Utara

[17] Sari, R. K. 2008. Adhesives from Tannin. Paper in MK Bio-Adhesive. Forestry Faculty IPB. Bogor. Unpublished. 